logos_i_ethos_2017_1_(44),s. 139-157

DOI: http://dx.doi.org/10.15633/lie.2125

Amadeusz Pala

Uniwersytet Papieski Jana Pawła II w Krakowie

\title{
Mistyka św. Jana od Krzyża w filozoficznej koncepcji miłości Karola Wojtyły?
}

W 1960 roku ukazało się studium etyczne zatytułowane Miłość i odpowiedzialność, będące książkową formą wykładów, jakie Karol Wojtyła Amadeusz Pala - mgr filozofii, doktorant na Wydziale Filozoficznym UPJPII, autor monografii Śmierć na miarę człowieka (Kraków 2014). wygłosił w latach 1958-59 na Katolickim Uniwersytecie Lubelskim ${ }^{1}$. Była to praca nowatorska jak na swoje czasy, a i dzisiaj pozostaje aktualna. Centralnym punktem zainteresowań Wojtyły była miłość, głównie ta małżeńska, między kobietą a mężczyzną. Koncepcja miłości Wojtyły była odpowiedzią na potrzebę ponownego namysłu nad ludzką miłością, spowodowaną postępującym procesem jej dehumanizacji, zwłaszcza w wymiarze seksualnym. Książka ma głównie charakter filozoficzny ${ }^{2}$, a pisana jest w duchu personalistycznym ${ }^{3}$.

Owa koncepcja miłości, jaka się wyłania z Miłości i odpowiedzialności, zbudowana jest przede wszystkim na trzech filozoficznych fundamentach. Pierwszym $z$ nich jest tomizm, który Wojtyła studiował począwszy od udziału w konspiracyjnym seminarium duchownym w Krakowie, aż po studia

1 Zob. K. Wojtyła, Miłość i odpowiedzialność, Lublin 2001, s. 7.

2 Książka ta zawiera w sobie również pewne elementy teologiczno-biblijne, zaś niniejszy artykuł jest próbą pokazania, że możemy w niej znaleźć także fragmenty inspirowane mistyką św. Jana od Krzyża.

3 Warto przytoczyć tu komentarz, jaki daje Rocco Buttiglione: „Książka zawiera analizę etyki seksualnej, która została umieszczona w perspektywie interpersonalnej. Jednakże rozdziały «Analiza słowa używać» oraz «Analiza etyczna miłości» zawierają przede wszystkim wykład zasad etyki personalistycznej, daleko wykraczający poza tę konkretną kwestię, której poświęcona jest książka. Natomiast sama struktura dzieła ukazuje nam model integracji analizy fenomenologicznej i perspektywy ontologicznej” (R. Buttiglione, Myśl Karola Wojtyly, Lublin 2010, s. 129-130). 
doktoranckie w Collegium Angelicum w Rzymie. Stanowił on dla niego swoistą podstawę filozofowania, potwierdzającą jego zdroworozsądkowy sposób ujmowania świata. Drugim zaś jest fenomenologia, z którą Wojtyła zapoznaje się bliżej w trakcie badań nad etyką Maxa Schelera ${ }^{4}$, w efekcie ocenia ją krytycznie, zauważając niebezpieczeństwo subiektywizmu oraz idealizmu, do których może prowadzić - stąd nie przejmuje jej w całości, ale bierze z niej przede wszystkim metodę opisu przeżyć człowieka ${ }^{5}$. Trzecim natomiast jest etyka Kanta, która jako filozofia podmiotowa zainspirowała Wojtyłę do głębszego namysłu nad kwestią godności człowieka, a w efekcie do utworzenia tak zwanej normy personalistycznej, będącej przeformułowaną i wzbogaconą wersją Kantowskiego imperatywu ${ }^{6}$ (co dokonuje się przy jednoczesnym odrzuceniu, podobnie jak w przypadku filozofii Schelera, subiektywizmu i idealizmu). W ten sposób Wojtyła w ramach swojej własnej filozofii będzie opierał się zarówno na filozofii przedmiotowej, filozofii bytu, jak i na filozofii podmiotowej, filozofii świadomości ${ }^{7}$. Jednak obok tych trzech zasadniczych fundamentów nadających kształt filozoficznej koncepcji miłości polskiego personalisty trzeba jeszcze wymienić czwarte źródło oddziaływania, jakim jest mistyka św. Jana

4 Zob. K. Wojtyła, Ocena możliwości zbudowania etyki chrześcijańskiej przy założeniach systemu Maxa Schelera, w: K. Wojtyła, Zagadnienie podmiotu moralności, Lublin 2001, s. 11-128.

${ }^{5}$ Oprócz tej metody Wojtyła od Schelera przejmuje też pewne idee dotyczące osoby, na przykład rolę, jaką odgrywają uczucia w strukturze osoby, czy też ideę miłości będącej odpowiedzią na wartość osoby. Zob. K. Wojtyła, Ocena możliwości zbudowania etyki chrześcijańskiej..., dz. cyt., passim.

${ }^{6}$ W kwestii tej Wojtyła pisze: „I. Kant sformułował tę elementarną zasadę porządku moralnego w następującym imperatywie: «Postępuj tak, aby osoba nigdy nie była tylko środkiem twego działania, ale zawsze celem». W świetle poprzednich wywodów zasada ta nie tyle winna być sformułowana w brzmieniu nadanym jej przez Kanta, ile raczej w brzmieniu następującym: «llekroć w twoim postępowaniu osoba jest przedmiotem działania, tylekroć pamiętaj, że nie możesz jej traktować tylko jako środka do celu, jako narzędzia, ale liczyć się z tym, że ona sama ma lub bodaj powinna mieć swój cel»" (K. Wojtyła, Miłość i odpowiedzialność, dz. cyt., s. 30).

7 W kontekście tym Zofia Zdybicka zauważa, że Wojtyła: „poprzez własny styl i metodę filozofowania dążył do połączenia przedmiotowego ujęcia człowieka - zgodnie z filozofią bytu wywodzącą się od Arystotelesa i św. Tomasza z Akwinu («zobiektywizowana metafizyka osoby») - z ujęciem świadomościowym, właściwym dla filozofii podmiotu (głównie Schelera). [...] Wojtyła uwzględniał i aspekt bytowy, i świadomościowy, a wykazując ich spójność, zawsze respektował pierwszeństwo horyzontu bytu przed horyzontem świadomości. Świadomość istnieje dlatego, że istnieje obiektywna rzeczywistość" (Z. Zdybicka, Wojtyła, w: Powszechna encyklopedia filozofii, t. 9, Lublin 2008, s. 816). 
od Krzyża, będąca przedmiotem badań Wojtyły, które prowadził głównie $w$ ramach pisania swojej pracy doktorskiej. Celem niniejszego artykułu jest właśnie pokazanie wpływu, jaki nauczanie Doktora Mistycznego mogło mieć na filozoficzną koncepcję miłości Wojtyły. Aby tego dokonać, zostanie najpierw streszczona owa koncepcja miłości, następnie będzie ukazana rola miłości, jaka wyłania się z mistyki św. Jana od Krzyża, aż w końcu dojdzie do próby ukazania pewnych elementów tej mistyki, które w przekonaniu piszącego te słowa mogły stanowić dla Wojtyły cenną inspirację.

\section{Filozoficzna koncepcja miłości Karola Wojtyły}

Wykład na temat miłości Wojtyła zaczyna od krótkiego nakreślenia swojej antropologii, przyjmując tradycyjne ujęcie człowieka jako osoby. Osoba jest dla Wojtyły bytem szczególnym, w niej ujawnia się pewien metapoziom: osoba pyta o sens i wartość swojego bytu. Pytanie to stawia na poziomie rozumności i wolności. „Osoba - pisze Wojtyła - jest to taki byt przedmiotowy, który jako określony podmiot, najściślej kontaktuje się z całym światem (zewnętrznym) i najgruntowniej w nim tkwi właśnie poprzez swoje wnętrze i życie wewnętrzne"s. Człowiek, angażując się w otaczający go świat, poznaje swoją osobę i rozwija swoją osobowość. Osoba to byt, który sam w sobie posiada nieskończoną wartość, dokładniej określaną jako godność, na którą jedyną adekwatną odpowiedzią jest miłość. Wyklucza to czysto utylitarny sposób traktowania człowieka-osoby, co Wojtyła podkreśla w sposób dość radykalny: „nikt nie może posługiwać się osobą jako środkiem do celu; ani człowiek, ani nawet Bóg-Stwórca. Właśnie ze strony Boga jest to najzupełniej wykluczone, gdyż On, dając osobie naturę rozumną i wolną, przez samo to już zdecydował, że będzie ona sama sobie określała cele działania"”.

Koncepcja miłości jest centralnym zagadnieniem etyki Wojtyły. Poprzez akt miłości podmiotu do przedmiotu, zmienia się przedmiot, czyli osoba obdarzana miłością, a jednocześnie dokonuje się zmiana w pod-

8 K. Wojtyła, Miłość i odpowiedzialność, dz. cyt., s. 25.

9 K. Wojtyła, Miłość i odpowiedzialność, dz. cyt., s. 29-30. 
miocie, bowiem akt miłości wpływa na samodoskonalenie się podmiotu. Ale ta relacja między podmiotem a przedmiotem jest także relacją między dwoma podmiotami, dlatego winna ją charakteryzować szczególna zasada moralna: „Ilekroć - powiada Wojtyła - w twoim postępowaniu osoba jest przedmiotem działania, tylekroć pamiętaj, że nie możesz jej traktować tylko jako środka do celu, jako narzędzia, ale liczyć się z tym, że ona sama ma lub bodaj powinna mieć swój cel"10. Co więcej, działanie w ramach tej relacji odbywa się w wolności, a przez to pociąga za sobą odpowiedzialność, która przebiega w trzech kierunkach: podmiot jest odpowiedzialny wobec siebie - za aktualizowanie swojej potencjalności (za realizowanie siebie), następnie wobec drugiej osoby - za skutki moralne, które w niej spowodował, oraz ostatecznie wobec Boga. Człowiek poprzez bytowanie we wspólnocie osób, oraz dokonywanie w niej działań społecznych, dojrzewa jako osoba. Dojrzewanie to jest oparte na normie personalistycznej, która wyraża powinność afirmacji godności osobowej każdego członka wspólnoty. Spoiwem wszystkich społeczności winna być miłość rozumiana jako wzajemny dar. Podstawową społecznością, wynikającą z natury człowieka jako mężczyzny i kobiety, jest małżeńska wspólnota miłości, z której może wypłynąć nowe życie, a przez to, która może się przerodzić we wspólnotę rodziny ${ }^{11}$.

Małżeństwo jednoczy w sposób trwały mężczyznę i kobietę dla wspólnego celu, którym jest realizowanie daru wzajemnej miłości. Cel ten wyraża się także we współżyciu seksualnym, uwzględniającym możliwość prokreacji. Miłość małżeńska jako miłość oblubieńcza ma moc integracji innych rodzajów miłości (miłość upodobania, pożądania i życzliwości), które wynikają z dynamizmu cielesno-duchowego. Owa integracja miłości, której znaczenie Wojtyła tak bardzo podkreśla, polega na „podpinaniu” poziomu cielesno-psychicznego pod poziom duchowy osoby. Stąd w pierwszej kolejności Wojtyła analizuje problem popędu seksualnego, wskazując na potrzebę przeniesienia go z poziomu instynktu na poziom osobowy, aby jego realizacja wypływała z miłości. Popęd seksualny musi

10 K. Wojtyła, Miłość i odpowiedzialność, dz. cyt., s. 30.

11 Zob. K. Wojtyła, Miłość i odpowiedzialność, dz. cyt., s. 30. 
być włączony w porządek miłości, co dokonuje się poprzez czystość, która nie jest postawą przeciwstawienia się wartościom seksualnym, wręcz przeciwnie, ona wyrywa je z poziomu czysto cielesnego i włącza w perspektywę personalistyczną ${ }^{12}$. Jeżeli zaś chodzi o miłość w jej aspekcie uczuciowym, to należy skonfrontować ją z prawdą o drugiej osobie. Człowiek, który kocha dojrzałą miłością, nie skupia się na własnych stanach uczuciowych i wyobrażeniach o drugiej osobie, która je w nim wywołuje, ale potrafi to wszystko przekroczyć i dostrzec prawdę o tej osobie - a dzięki takiemu spojrzeniu może szukać jak najlepszego sposobu, aby służyć jej dobru, a nie tylko swojemu egoistycznemu interesowi ${ }^{13}$.

Filozoficzna koncepcja miłości Karola Wojtyły dotyczy zatem sensu istnienia każdej osoby, jakim jest nawiązanie głębokiej, jednoczącej relacji z drugą osobą ( $\mathrm{z}$ człowiekiem, a docelowo także z Bogiem). Jest to więc koncepcja mówiąca, że szczęściem człowieka jako osoby może być tylko miłość, ponieważ tylko ona jest adekwatną odpowiedzią na pragnienia, które rodzą się w człowieku za sprawą jego godności osobowej ${ }^{14}$.

\section{Miłość w mistyce św. Jana od Krzyża}

Owocem spotkania Wojtyły z myślą hiszpańskiego mistyka św. Jana od Krzyża ${ }^{15}$ była jego rozprawa doktorska z 1948 roku zatytułowana Problem wiary według św. Jana od Krzyża (Questio de Fide apud S. Joannem a Cru-

12 Zob. K. Wojtyła, Miłość i odpowiedzialność, dz. cyt., s. 45-47.

13 Zob. K. Wojtyła, Miłość i odpowiedzialność, dz. cyt., s. 99-103.

14 „Miłość, czyli afirmacja wartości innej osoby wyrażona czynem, który «istotowo jest darem», jest najwyższym i najważniejszym aktem osoby ludzkiej, w której osoba wyraża się i równocześnie spełnia sens swego życia, realizuje swoje człowiecze powołanie, które jest wezwaniem do doskonałości przez miłość. [...] Afirmacja drugiego jest jednocześnie samodoskonaleniem się osoby. Stanowi także najdoskonalszy wyraz ludzkiej wolności - samostanowienia” (Z. Zdybicka, Wojtyła, w: Powszechna encyklopedia filozofii, dz. cyt., s. 820).

15 Wojtyła został wprowadzony w świat tej mistyki dzięki znajomości z Janem Tyranowskim, człowiekiem świeckim, krawcem z zawodu, który w czasie okupacji hitlerowskiej prowadził zebrania Żywego Różańca dla młodzieży męskiej organizowane przy parafii św. Stanisława Kostki na Dębnikach w Krakowie. Zob. K. Wojtyła, Apostoł, w: K. Wojtyła, Aby Chrystus się nami posługiwał, wybór J. Hennelowa, Kraków 1979, s. 26. 
$c e)^{16}$. Choć, jak zdradza tytuł, autor skupia się w niej przede wszystkim na wyłożeniu koncepcji wiary samej w sobie ${ }^{17}$, to jednak okazuje się, że miłość odgrywa tu równie znaczącą rolę.

W swojej rozprawie doktorskiej Wojtyła stara się pokazać, że celem mistycznej doktryny św. Jana od Krzyża jest wyłożenie sposobu, w jaki człowiek może osiągnąć jak najbliższą więź z Bogiem, a nawet zjednoczenie się z Nim. A dzieje się to dzięki wierze, która jest tu pojęta jako jedyny środek umożliwiający zjednoczenie duszy z Bogiem. Trzeba jednocześnie podkreślić, że nie chodzi o zjednoczenie w porządku natury czy o zjednoczenie substancjalne, ale mowa o zjednoczeniu nadprzyrodzonym przez podobieństwo ${ }^{18}$.

Zgodnie z nauką hiszpańskiego mistyka każda cnota teologiczna (wiara, nadzieja, miłość) jednoczy z Bogiem podporządkowaną sobie władzę duszy (są to odpowiednio: rozum, pamięć, wola), robi to poprzez oczyszczenie każdej władzy, wnikając jako przedmiot nadprzyrodzony do wnętrza tych władz ${ }^{19}$. Za pośrednictwem tychże cnót każda władza jest formowana na sposób nadprzyrodzony. Widać jasno, że miłość jest odpowiedzialna za formowanie woli: przenika jej naturę i pozbawia ją stopniowo pierwiastka przyrodzonego, kształtując nadprzyrodzony, oddzielając w konsekwencji wolę od tego, co stworzone i jednocząc z Bogiem. Całościowe zaś oczyszczenie duszy z tego, co w niej niedoskonałe, przyrodzone jest dla niej swoistym cierpieniem, przybierającym postać tytułowej Nocy ciemnej, o której św. Jan od Krzyża poucza: „Ta noc, którą [...] jest kontemplacja, powoduje w duszy podwójny rodzaj ciemności albo oczyszczenia, stosownie do dwóch części człowieka, to jest jego części zmysłowej i duchowej. Jedna noc zatem jest oczyszczeniem części zmysłowej.

16 Początkowo Wojtyła napisał pracę magisterską z teologii zatytułowaną Pojęcie środka zjednoczenia duszy z Bogiem w nauce świętego Jana od Krzyża. Obronił ją w „podziemnym” Krakowskim Seminarium Duchownym. Następnie podczas studiów na Angelicum w Rzymie (1946-1948) rozwinął i pogłębił swoją pracę, co zaowocowało uznaniem jej za pracę doktorską. Zob. J. Galarowicz, Człowiek jest osobą. Podstawy antropologii filozoficznej Karola Wojtyły, Kraków 1994, s. 14-15.

17 Zob. K. Wojtyła, Świętego Jana od Krzyża nauka o wierze, Lublin 2000, s. 22.

18 Zob. K. Wojtyła, Świętego Jana od Krzyża nauka o wierze, dz. cyt., s. 38.

19 Por. Św. Jan od Krzyża, Droga na Górę Karmel, Kraków 2001, s. 117. 
Oczyszcza się tu dusza co do zmysłów, aby je całkowicie dostosować do ducha. Druga noc jest oczyszczeniem ducha. Oczyszcza się w niej i ogołaca duchowa część duszy, dostosowując się i przygotowując do zjednoczenia miłości z Bogiem"20. Dodajmy, że główną cnotą obok wiary pomagającą duszy przetrwać tę noc jest właśnie największa teologiczna cnota - miłość (zob. 1 Kor 13, 13). Święty Doktor mówi do duszy wprost: „te dwie cnoty są przewodnikami ślepego i zaprowadzą cię tam, gdzie sama nigdy byś dojść nie mogła, czyli do tego ukrycia, gdzie Bóg przebywa"21.

Miłość zatem w mistyce św. Jana od Krzyża odgrywa ważną rolę, bo to ona właśnie jest siłą pogłębiającą owo zjednoczenie duszy z Bogiem $^{22}$. Dzięki miłości dokonuje się wręcz szczególne przeobrażenie duszy w Boga, a jest to „przeobrażenie przez uczestnictwo”"23. Miłość powoduje wzrost zjednoczenia, a w efekcie nadprzyrodzone przeobrażenie, co także idzie w parze ze wzrostem zgodności woli duszy z wolą Boga. Jednak jak podkreśla Wojtyła, „przeobrażenie nie przekracza nigdy granic uczestnictwa" ${ }^{24}$. Mimo to można powiedzieć za św. Janem od Krzyża, że dusza „wydaje się wtedy być więcej Bogiem niż duszą i w rzeczy samej jest Bogiem przez uczestnictwo"25. Mówiąc nieco jaśniej, uczestnictwo polega na takiej relacji duszy i Boga, która jest relacją wzajemnego daru, w wyniku którego obie strony ofiarują się sobie nawzajem aż tak daleko, że przebywają wzajemnie w swych osobowych wnętrzach, nie tracąc jednocześnie różnicy między sobą ${ }^{26}$. Aby podkreślić jeszcze bar-

20 Św. Jan od Krzyża, Noc ciemna, Kraków 2001, s. 53.

${ }^{21}$ Św. Jan od Krzyża, Pieśń duchowa, Kraków 2002, s. 39.

${ }_{22}$ Zob. K. Wojtyła, Świętego Jana od Krzyża nauka o wierze, dz. cyt., s. 39. Wojtyła pisze: „Święty Autor [...] kładzie nacisk na znaczenie miłości w osiągnięciu i pogłębieniu zjednoczenia. Stąd od razu jawi się właściwość dynamiczna zjednoczenia, o jakim mowa: zjednoczenie polega na nadprzyrodzonym uczestnictwie w Boskim «esse» przez łaskę i miłość. Właśnie też dzięki miłości ma ono moc wzrostu" (K. Wojtyła, Świętego Jana od Krzyża nauka o wierze, dz. cyt., s. 39).

${ }^{23}$ K. Wojtyła, Świętego Jana od Krzyża nauka o wierze, dz. cyt., s. 40.

24 K. Wojtyła, Świętego Jana od Krzyża nauka o wierze, dz. cyt., s. 41.

25 Św. Jan od Krzyża, Droga na Górę Karmel, dz. cyt., s. 115.

26 „Miłość w tym mistycznym zjednoczeniu nie niweczy miłości ludzkiej, ale nadaje jej nowe znamiona, znamiona pełni, obfitości i wiecznego trwania" (T. Biesaga, Mistyka i metafizyka wantropologii Karola Wojtyly, w: Wokół antropologii Karola Wojtyły, red. A. Maryniarczyk, P. Sulenta, T. Duma, Lublin 2016, s. 66). 
dziej znaczenie miłości w mistyce św. Jana od Krzyża, można zestawić je ze znaczeniem wiary, przytaczając dwa fragmenty z pracy Wojtyły. Pisze on bowiem, że „rozum dzięki niej [wierze - A. P.] nie staje się zdolny do przeobrażenia się pod wpływem Bóstwa w ten sposób, jak przeobraża się wola pod wpływem miłości”27. A także: „całe to działanie wiary, o jakim była mowa, podporządkowane jest miłości” ${ }^{28}$. Ze słów tych płynie zatem wniosek, że dusza nie tyle $\mathrm{w}$ akcie samej wiary, ale dopiero $\mathrm{w}$ akcie miłości staje się podobna do Tego, kogo kocha.

Miłość wraz z wiarą zajmuje więc pierwszoplanowe miejsce w mistyce św. Jana od Krzyża dotyczącej zjednoczenia duszy z Bogiem. Zjednoczenie to może mieć różny poziom, który zależy w dużym stopniu od tego, jak mocno człowiek żyje miłością (ale także od tego, jak Bóg udziela się duszy poprzez łaskę). Dusza dzięki miłości uczestniczy w życiu Boga, choć jest ono dla niej swoistym „trudem uczestnictwa”: „Jest to trud w którym człowiek ciągle przechodzi siebie, aby uchwycić, zaktualizować głębiej tę postać życia, które chociaż w nim jest i w nim się staje, niemniej z natury nie jest jego własnością, ale darem"29. Trud ten polega na ciągłym byciu gotowym na przyjęcie daru, na uznaniu łaski i wierności jej, i na transcendowaniu poprzez akty miłości, czyli przekraczaniu siebie w kierunku wyznaczonym przez nowe możliwości, o których poucza wiara ${ }^{30}$.

\section{Wpływ mistyki św. Jana od Krzyża na Wojtyłowską koncepcję miłości}

Można spróbować postawić tezę, że mistyka św. Jana od Krzyża wywarła na filozoficzną koncepcję miłości Karola Wojtyły dwojaki rodzaj wpływu: pośredni i bezpośredni. Wpływ pośredni byłby rozumiany jako jedna z przyczyn ${ }^{31}$ przyjęcia przez Wojtyłę specyficznej postawy filozo-

27 K. Wojtyła, Świętego Jana od Krzyża nauka o wierze, dz. cyt., s. 86.

28 K. Wojtyła, Świętego Jana od Krzyża nauka o wierze, dz. cyt., s. 114.

29 K. Wojtyła, Świętego Jana od Krzyża nauka o wierze, dz. cyt., s. 241.

30 Por. J. Galarowicz, Człowiek jest osobą..., dz. cyt., s. 31.

31 Przyczyn tych było zapewne wiele. Wśród nich mogły być nawet doświadczenia osobiste czy dramaty życiowe, które kształtowały charakter Wojtyły od wczesnego dzieciństwa. 
ficznej, która zawiera w sobie dwa sposoby filozofowania: tomistyczny - akcentujący aspekt obiektywny, bytowy oraz fenomenologiczny akcentujący aspekt subiektywny, świadomościowy. Postawa ta bowiem, a więc $\mathrm{z}$ jednej strony metafizyczne, realistyczne założenia, $\mathrm{z}$ drugiej zaś fenomenologiczna metoda badawcza, warunkowała podejście Wojtyły do tematu miłości międzyosobowej. Natomiast bezpośredniego rodzaju wpływu można się doszukiwać przede wszystkim we fragmentach zawartych w Miłości i odpowiedzialności, gdzie poruszany jest temat tak zwanej miłości oblubieńczej, która nastawiona jest, podobnie jak w mistyce św. Jana od Krzyża, na zjednoczenie osób. Zarówno wpływ pośredni, jak i bezpośredni zostaną teraz omówione nieco szerzej.

\section{a. Wpływ pośredni}

Aby pokazać pośredni ${ }^{32}$ rodzaj wpływu, trzeba powrócić na chwilę do wątku relacji, jaka zachodziła między wiarą a miłością u hiszpańskiego mistyka. Powiedziano bowiem wcześniej, że fakt ten dostrzega i podkreśla sam Wojtyła. I można wręcz przeczytać u niego o wierze, która „żyje przez miłość, która ustawicznie napełnia się miłością, od której też otrzymuje równocześnie formę swego zjednoczenia z Bogiem" ${ }^{33}$. W tym miejscu trzeba więc zauważyć, że termin „forma” zdaje się nawiązywać do koncepcji formy i materii Arystotelesa, a dzięki słowom samego św. Jana od Krzyża nawiązanie to powinno się jeszcze bardziej rozjaśnić: „Miłość bowiem przenika tym samym sposobem co forma materię, wchodząc w duszę w jednym momencie"34. Porównanie koncepcji miłości formującej duszę do formy przenikającej materię mówi o zasad-

32 Wpływ pośredni możemy nazwać również wpływem formalnym, czyli wpływem na przyjęcie konkretnego sposobu filozofowania przez Wojtyłę.

${ }^{33}$ K. Wojtyła, Świętego Jana od Krzyża nauka o wierze, dz. cyt., s. 117. W kontekście tym można więc powiedzieć, że miłość jest życiem wiary, czy też powiedzieć za św. Pawłem, że „wiara, [...] działa przez miłość" (Ga 5, 6).

34 Św. Jan od Krzyża, Żywy płomień miłości, Kraków 2003, s. 47. Po hiszpańsku zdanie to brzmi: „E introdúcese el amor al modo que la forma en la materia, que se introduce en un instante” (San Juan de la Cruz, Llama de Amor Viva B, 33). 
niczej (aktualizującej) funkcji miłości w procesie zjednoczenia osoby ludzkiej z osobowym Bogiem. Jednocześnie spostrzeżenie to uprawnia do postawienia nauki św. Jana od Krzyża w niedalekiej odległości od myśli św. Tomasza z Akwinu, która - jak przypomina Wojtyła - charakteryzuje się nauką o „środkach zjednoczenia”, odrzucając „,zjednoczenie bez pośrednictwa" ${ }^{35}$.

Ale trzeba równocześnie przyznać, że porównywanie myśli hiszpańskiego mistyka z myślą Akwinaty może wydawać się na pierwszy rzut oka czymś nieodpowiednim, gdyż mistyce jako takiej zawsze bliżej będzie do augustynizmu niż do tomizmu. I oczywiście jest w tym wiele racji, zważywszy choćby na krytyczny stosunek Doktora Mistycznego do ciała, w ramach którego wysuwa postulat zaparcia się owej zewnętrzności ludzkiej, skutkujący urzeczywistnieniem się tak zwanej nocy ciemnej, prowadzącej do doskonalszego życia duchowego (czego zresztą nie podziela Wojtyła, który w Miłości i odpowiedzialności będzie wskazywał raczej na potrzebę dowartościowania ciała, co ma więcej wspólnego z podejściem Akwinaty). Dalej trzeba również przyznać, że sama metoda zawarta w pismach hiszpańskiego mistyka nie ma nic wspólnego z traktatem metafizycznym, ale jest raczej pewną fenomenologią doświadczenia mistycznego, a więc dokładnym opisem tego doświadczenia, mającym pokazywać, że spotkanie z Bogiem w swojej najwyższej formie przebiega bez udziału jakichkolwiek doznań cielesnych czy emocji. Mimo tych zastrzeżeń, powyższe słowa św. Jana od Krzyża, w których mówi, że miłość przenika duszę podobnie jak forma przenika materię, są dość konkretnym dowodem na występowanie przynajmniej pewnych tomistycznych elementów w tej mistyce. Twierdzenie to uprawnia zatem do wniosku, że w nauce Doktora Mistycznego są równocześnie obecne dwa sposoby ujmowania człowieka, wywodzące się z dwóch tradycji, augustynizmu i tomizmu, a już na pewno nauka ta nie jest całkowicie sprzeczna $\mathrm{z}$ myślą tomaszową ${ }^{36}$. Na poparcie tego wniosku warto zacytować tu jeszcze

35 Por. K. Wojtyła, Świętego Jana od Krzyża nauka o wierze, dz. cyt., s. 17.

36 Wojtyła, będąc tego prawdopodobnie świadomy, nie zatracił jednocześnie swojego zmysłu krytycznego - zauważył bowiem pewną niejasność polegającą na tym, że dla św. Jana od Krzyża, 
słowa o. Serafina M. od Trójcy Przenajświętszej OCD, jednego z badaczy myśli hiszpańskiego mistyka, który pisze: „Na koniec spójrzmy jeszcze na źródła literackie i doktrynalne, których oddźwięki znajdujemy w dziełach św. Jana od Krzyża, czasem w sposób bezpośredni, czasem pośrednio. Przede wszystkim należy tu wymienić tomizm i późną scholastykę hiszpańską, które dają św. Janowi od Krzyża pewną strukturę filozoficzną dla jego dzieła. Następnie wpływ św. Augustyna i neoplatonizmu, które wzbogacają św. Jana od Krzyża o pewną dynamikę"37. Podobnego zdania jest o. Otto Filek OCD, który we wprowadzeniu do polskiej edycji dzieł Doktora Mistycznego stwierdza: „Jan od Krzyża jest wiernym tomistą. Naukę św. Tomasza przyswoił sobie dzięki mistrzom salamanckim, wykładającym przeważnie Sumę teologiczną. W pewnych jednak szczegółach znać w nim wpływ i innych prądów myśli. Na przykład ze względów praktycznych przyjął od św. Augustyna podział na trzy władze duszy"38.

Twierdzi się zatem, że taka postać mistyki św. Jana od Krzyża, godząca w sobie różne sposoby filozofowania, mogła stać się dla młodego Wojtyły jedną z inspiracji, które sprawiły, że i on zdecydował się w ramach swojej własnej filozofii na uprawianie jej, czerpiąc z nurtów będących względem

podobnie jak dla św. Tomasza, wiara to „proporcjonalny środek”, umożliwiający spotkanie człowieka z Bogiem, ustanawiający proporcję podobieństwa między człowiekiem a Bogiem, ale jednocześnie dla hiszpańskiego mistyka jest to „wiara ciemna”, w której intelekt rezygnuje ze swoich roszczeń poznawczych, podczas gdy dla Akwinaty wiara to wręcz „cnota intelektu”. Wojtyła twierdzi, że jest to tylko pozorna aporia, wyjaśniając, że według św. Jana od Krzyża wiara „ubogaca darami Ducha”, a przede wszystkim darem rozumienia (co właśnie ma godzić tę wiarę z wiarą św. Tomasza); wiara jest związana z intencjonalnym dążeniem człowieka ku Bogu, a takie dążenie angażuje wszystkie jego władze i cnoty. Stąd ciemność wiary i jednocześnie obecność intelektualnego poznania nie rodzą sprzeczności, wręcz przeciwnie: światło Bożej prawdy, które jest przyczyną tego intelektualnego poznania u człowieka, jest tak mocne, że oślepia człowieka, powodując ową „ciemność”. Widać zatem, że nie jest to zwykła ciemność, która byłaby powodem jakiejś istotnej sprzeczności. O problemie tym Buttiglione pisze: „W nocy, w której milczą wszelkie uczucia, człowiek doświadcza absolutnego oddalenia od Boga, doświadcza niepojmowalności Boga [...]. Pozytywna wiedza o Bogu nie jest możliwa - w tym miejscu hiszpański mistyk zgadza się w pełni ze św. Tomaszem. Jednakże w przeżyciu wiary człowiek rzeczywiście spotyka się z Bogiem, Bóg staje się formą jego intelektu" (R. Buttiglione, Myśl Karola Wojtyły, dz. cyt., s. 89).

37 o. Serafin M. od Trójcy Przenajświętszej OCD, Geniusz św. Jana od Krzyża, Poznań 2009, s. 25.

38 O. Filek, Wprowadzenie, w: Jan od Krzyża, Dzieła, Kraków 1995, s. 53. 
siebie w pewnym filozoficznym „napięciu”. Mówiąc wprost, zobaczył on, na przykładzie myśli hiszpańskiego mistyka, że możliwe jest prowadzenie rozważań w sposób bogatszy, uwzględniający aspekt podmiotowy i przedmiotowy (nawet jeżeli jeden $\mathrm{z}$ nich ma dominować). Nie znaczy to oczywiście, że charakter filozofii Wojtyły wywodzi się wprost i wyłącznie z mistyki św. Jana od Krzyża. Takie twierdzenie byłoby z pewnością nadużyciem, bowiem filozofia ta, jak zaznaczono we wstępie, ma swoje bezpośrednie źródła głównie w tomizmie i w recepcji metody fenomenologicznego opisu przeżyć dokonanej po konstruktywnej krytyce etyki Schelera. Twierdzi się jedynie, że mistyka najprawdopodobniej była cenną inspiracją dla młodego Wojtyły, mogącą rozbudzić w nim coś na kształt „przeczucia” na temat tego, jaką filozoficzną drogą powinien podążać w przyszłości ${ }^{39}$. Słowa te zdają się mieć swoje potwierdzenie już na pierwszych stronach Miłości i odpowiedzialności, gdzie można przeczytać o tym, że tylko człowiek jako byt jest podmiotem i przedmiotem zarazem. Przy czym Wojtyła zaznacza wyraźnie, że przedmiotowość pojęta jako obiektywizm, a wraz z nim realizm, należy wysunąć na plan pierwszy, po to, aby świat, który istnieje poza podmiotem, nie był przez niego

39 Na dowód tego warto dodać, że jego praca doktorska doczekała się kontynuacji w postaci artykułu O humanizmie św. Jana od Krzyża (1951), który świadczy, że tym, co najbardziej interesowało Wojtyłę w poglądach karmelity, był sam człowiek jako podmiot poznania i działania. Te zainteresowania humanistyczne doprowadziły Wojtyłę do napisania swojej głównej pracy filozoficznej, której nadał tytuł Osoba i czyn. Zdaniem Tadeusza Biesagi „można nawet powiedzieć, że dzięki przeżyciom mistycznej, kontemplatywnej jedności z Bogiem, opisanym przez mistyków i poszukiwanym w swoich drogach rozwoju duchowego, Wojtyła nie uległ modnym w naszych czasach, naukowym, pozytywistycznym opisom człowieka jako jednego z wielu przedmiotów przyrody. Odkrycie przez niego intuicji osoby, jej godności, jej wyjątkowości, dokonało się już wtedy, gdy uświadomił sobie, jaka przedziwna relacja zachodzi w jedności mistycznej i kontemplacyjnej między człowiekiem a Bogiem. [...] W tym kontekście przeżycie mistyczne, którym zafascynował się Wojtyła, przyczyniło się do odnowienia przez niego antropologii czy etyki. W całym swoim życiu był filozofem wielkości człowieka. W wieku kataklizmów antropologicznych - nazizmu i komunizmu, w wieku sceptycyzmu i nihilizmu, stał się tym, który uparcie przywracał osobowe, duchowe oblicze człowieka. Wobec redukcji podmiotu ludzkiego w heglizmie, marksizmie, freudyzmie, strukturalizmie i technokratyzmie - odkrywał na nowo podmiotowość każdego, konkretnego człowieka, jego niezbywalną wartość, osobową godność. Odkrycie osobowej podmiotowości i godności pozwalało mu krytycznie ocenić wszelkie przejawy dehumanizacji naszej kultury, jako kultury śmierci i pełzającego totalitaryzmu" (T. Biesaga, Mistyka i metafizyka w antropologii Karola Wojtyly, dz. cyt., s. 66). 
traktowany w sposób czysto podmiotowy, subiektywny - czyli zawarty $\mathrm{w}$ świadomości podmiotu ${ }^{40}$. To stanowisko odgrywa więc kluczową rolę, ponieważ na jego kanwie Wojtyła będzie prowadził swoje szczegółowe rozważania antropologiczne, dotyczące między innymi miłości, która się rodzi ze spotkania osób.

Jednocześnie trzeba zaznaczyć, że ów pośredni rodzaj wpływu stanowi nieco mniej istotny wątek, który jednak został tu naświetlony w celu lepszego naprowadzenia na odpowiedniejszy dla podjętego tematu drugi rodzaj wpływu, jakim jest wpływ bezpośredni.

\section{b. Wpływ bezpośredni}

Jeżeli więc chodzi o bezpośredni ${ }^{41}$ rodzaj wpływu, jaki mogła wywrzeć mistyka św. Jana od Krzyża na filozoficzną koncepcję miłości Karola Wojtyły, to można go dostrzec we fragmentach Miłości i odpowiedzialności, które dotyczą tak zwanej miłości oblubieńczej. Aby wpływ ten pokazać, trzeba najpierw pokrótce powiedzieć, co charakteryzuje miłość oblubieńczą. Dla Wojtyły jest ona bowiem najwznioślejszym aspektem miłości (skupia się na niej po wcześniejszym omówieniu miłości pojętej jako upodobanie, pożądanie i życzliwość). W miłości oblubieńczej dochodzi do tego, że osoba nie tylko chce dobra dla drugiej osoby, ale sama się jej oddaje jako dobro. Ale szczególnym warunkiem oddania siebie drugiemu jest najpierw posiadanie siebie, które oznacza panowanie nad sobą samym. Oddanie oblubieńcze jest oddaniem indywidualnym mężczyzny i kobiety, oddaniem na wyłączność - i tym się różni od oddania się na przykład matki dla dziecka albo lekarza dla chorego. Aby mężczyzna i kobieta oddali się sobie, muszą niejako „podpiąć” poziom fizyczno-psychiczny, na którym przeżywają swoją miłość, pod poziom osobowy, ponieważ dopiero taki zintegrowany, personalistyczny wymiar miłości wyraża prawdziwe oddanie oblubieńcze. $Z$ takiej bliskości może

40 Por. K. Wojtyła, Miłość i odpowiedzialność, dz. cyt., s. 23.

41 Wpływ bezpośredni możemy określić również jako wpływ przedmiotowy, czy też treściowy, który wprost dotyczy ujęcia miłości międzyosobowej. 
się w sposób właściwy zrodzić miłość przyjmująca swój owoc, nową osobę, dziecko. Miłość ta może się wyrażać nie tylko w stanie małżeńskim, ale i w stanie konsekrowanym, w wyłącznej służbie Bogu ${ }^{42}$.

W tym miejscu należy się zatrzymać i powrócić do rozważań na temat miłości, które Wojtyła prowadził, komentując naukę Doktora Mistycznego. Warto przytoczyć tu szczególnie dwa cytaty z pracy doktorskiej Wojtyły. W pierwszym z nich napisał on: „miłość bowiem ma moc czynienia równymi i podobnymi kochającego i kochanego. Kiedy więc mowa jest o zjednoczeniu w płaszczyźnie podobieństwa [...], winna być tu wskazana jedynie miłość jako właściwa moc jednocząca"43. W drugim zaś miejscu mówi, że „miłość sama przez się jest przeobrażająca, sama przez się przyrównuje i upodabnia do kochanego - kochającego, który przyjmuje intencjonalnie jego formę" ${ }^{34}$. Oba te fragmenty dotyczą więc miłości jednoczącej kochające się osoby. Można więc wysunąć przypuszczenie, że koncepcja ta oddziałała na Wojtyłę, stając się cenną inspiracją dla rozwinięcia wątku, jaki prowadzi w Miłości i odpowiedzialności na temat miłości oblubieńczej ${ }^{45}$. Nawiązując bowiem raz jeszcze do tego najwznioślejszego wymiaru miłości, należy powiedzieć, że Wojtyła akcentuje w sposób szczególny właśnie motyw zjednoczenia się osób. Trzeba nawet odnotować, że na kartach swojej pracy pisze o nim dwukrotnie, raz w podrozdziale zatytułowanym Miłość oblubień$c z a$, a drugi raz wraca do niego w podrozdziale Przynależność osoby do osoby. Co prawda, zarówno w jednym, jak i w drugim miejscu zgadza się na metafizyczne założenie, wedle którego zjednoczenie osób jest niemożliwe w porządku natury, gdyż osoba jest nieprzekazywalna $\mathrm{z}$ istoty (alteri incommunicabilis) ${ }^{46}$, ale równocześnie mówi o możliwym zjed-

42 Zob. K. Wojtyła, Miłość i odpowiedzialność, dz. cyt., s. 87-92.

43 K. Wojtyła, Świętego Jana od Krzyża nauka o wierze, dz. cyt., s. 82.

44 K. Wojtyła, Świętego Jana od Krzyża nauka o wierze, dz. cyt., s. 93.

45 Zdaniem Biesagi: „Tak więc już w personalistycznym opisie doświadczenia mistycznego, jako doświadczenia międzyosobowego, rodzi się zasada personalistyczna w antropologii Wojtyły, która pełniejsze wydobycie i praktyczne zastosowanie znajdzie w jego książce Miłość i odpowiedzialność" (T. Biesaga, Mistyka i metafizyka w antropologii Karola Wojtyly, dz. cyt., s. 71).

46 „Każda osoba z istoty swej jest nieprzekazywalna - alteri incommunicabilis. Jest więc nie tylko panią samej siebie (sui iuris), ale także nie może siebie odstąpić czy oddać. Takiemu oddaniu 
noczeniu w porządku miłości i w znaczeniu moralnym. Wojtyła otwarcie przyznaje, że jest w tym swoisty paradoks miłości, pisze: „Istotnie, w problemie miłości oblubieńczej zawiera się jakiś głęboki paradoks, nie werbalny tylko, ale na wskroś realny; [...] Paradoks jest w tym wypadku podwójny i idzie w dwóch kierunkach: po pierwsze - że można tak wyjść z własnego «ja», a po drugie - że się przy tym owego «ja» bynajmniej nie niszczy i nie dewaluuje, ale wręcz przeciwnie, rozwija się je i bogaci w znaczeniu oczywiście ponad-fizycznym, w znaczeniu moralnym" 47 . Co istotne, w owym drugim podrozdziale stwierdza nawet dobitniej: „Otóż miłość wyrywa niejako osobę z tej naturalnej nienaruszalności i nie-odstępności. Miłość bowiem sprawia, że osoba właśnie chce siebie oddać innej - tej, którą kocha. Chce niejako przestać być swoją wyłączną własnością, a stać się własnością tej drugiej. Oznacza to pewną rezygnację z owego sui iuris oraz z owego alteri incommunicabilis. Miłość idzie poprzez taką rezygnację, kieruje się jednak tym głębokim przeświadczeniem, że rezygnacja ta prowadzi nie do pomniejszenia i zubożenia, ale wręcz przeciwnie - do rozszerzenia i wzbogacenia egzystencji osoby. Jest to jakby prawo «ekstazy» - wyjścia z siebie, aby tym pełniej bytować w drugim. W żadnej innej formie miłości prawo to nie realizuje się w sposób tak wyraźny jak w miłości oblubieńczej"48. I właśnie dochodzimy do miejsca, w którym trzeba podkreślić, że Wojtyła, pisząc o prawie „ekstazy”, zdaje się wprost nawiązywać do tradycji mistycznej, w ramach której owo prawo funkcjonuje - a nie ulega wątpliwości, że najbliższą mu mistyką byłą mistyka św. Jana od Krzyża, którą dogłębnie zbadał, i można przypuszczać (zważywszy na powszechnie znany

siebie samej sprzeciwia się natura osoby" (K. Wojtyła, Miłość i odpowiedzialność, dz. cyt., s. 88). „Z natury, czyli z racji tego, jakim jest bytem, osoba jest panem siebie samej (sui iuris) i nie może być odstąpiona innej ani też zastąpiona przez inną w tym, co domaga się udziału jej własnej woli i zaangażowania jej osobowej wolności (alteri incommunicabilis)" (K. Wojtyła, Miłość i odpowiedzialność, dz. cyt., s. 112).

47 K. Wojtyła, Miłość i odpowiedzialność, dz. cyt., s. 89. Wojtyła powołuje się tu na słowa Ewangelii: „Kto by chciał ocalić duszę swoją, ten ją straci, a kto by utracił duszę swoją dla mnie, ten ją znajdzie" (Mt 10, 39).

${ }^{48}$ K. Wojtyła, Miłość i odpowiedzialność, dz. cyt., s. 112-113. 
życiorys Wojtyły), że również w jakimś stopniu przyswoił i praktykował ${ }^{49}$. Warto jednak zwrócić uwagę na jeszcze jedno wcześniejsze sformułowanie, którego używa w przytoczonym właśnie cytacie, gdy mówi o "głębokim przeświadczeniu” co do tego, że akt miłości oblubieńczej, będąc wprawdzie swego rodzaju rezygnacją z siebie, nie doprowadzi do deprecjacji, ale do afirmacji własnej osoby. Wydaje się więc, że relacja, jaka zachodzi między takim „głębokim przeświadczeniem” a owym „ryzykiem miłości”, do podjęcia którego przeświadczenie to zachęca, ma wiele wspólnego z tą relacją, jaka zachodziła między wiarą a miłością w ramach mistyki św. Jana od Krzyża, gdzie wiara była niejako bramą umożliwiającą duszy wejście na konkretną drogę miłości prowadzącą przez noc ciemną do Boga.

Powyższe spostrzeżenia prowadzą do wniosku, że mistyka św. Jana od Krzyża mogła mieć bezpośredni wpływ na filozoficzną koncepcję miłości Karola Wojtyły w jej aspekcie dotyczącym zjednoczenia osób w ramach miłości oblubieńczej. Taka logika miłości, która sprawia, że osoba oddaje się na własność drugiej osobie, a jednocześnie dzięki temu jest niejako „bardziej sobą”, zdaje się być logiką, która mogła wypłynąć tylko z jednego źródła - mistycznego. Najwyraźniej Wojtyle nie wystarczały wnioski, do których mógł dojść dzięki metafizycznemu założeniu o nieprzekazywalności osoby, dlatego zdecydował się na włącznie do swojej koncepcji możliwości nadprzyrodzonego zjednoczenia osób w porządku miłości ${ }^{50}$. Nie znaczy to jednak, że odrzucił przez to ów metafizyczny postulat, wręcz przeciwnie, był świadomy jego konieczności, co przyznaje,

49 Podobną opinię prezentuje Zofia Zdybicka, która pisze: „«Myśliciel i mistyk» - to dwie kategorie, które w osobie, życiu i działaniu Jana Pawła II występują nierozdzielnie, dopełniają się i wydają się najgłębiej charakteryzować i wyjaśniać osobowość oraz niezwykłe owoce jego działania” (Z. Zdybicka, Jan Paweł II - Filozof i mistyk, Lublin 2009, s. 107).

50 Zjednoczenie ujęte w postaci relacji poznawczej podmiot-przedmiot, dobrze opisują słowa Jacques’a Maritaina, który pisze, że: „dopiero miłość znosi tę niemożność poznania drugiego człowieka inaczej, niż jako przedmiot [...]. Gdy mówimy, że przez zjednoczenie w miłości kochana przez nas istota staje się dla nas naszym drugim ja, mówimy, że staje się dla nas drugą podmiotowością, drugą naszą podmiotowością. [...] Poznajemy ją w samej jej podmiotowości, przynajmniej do pewnego stopnia, dzięki przeżywanemu zjednoczeniu" (J. Maritain, Pisma filozoficzne, Kraków 1988, s. 97-98). 
pisząc otwarcie o paradoksie, który się w ten sposób pojawia. Mistyka dla Wojtyły nie była więc czymś, co przeczy klasycznej metafizyce, ale raczej czymś, co ją dopełnia, a owocem tego dopełnienia stało się ubogacenie jego koncepcji miłości ${ }^{51}$.

\section{Podsumowanie}

Potrzeba pełniejszego spojrzenia na rzeczywistość ludzką towarzyszyła Wojtyle w trakcie całej jego filozoficznej działalności: przede wszystkim dopełniał spekulatywne analizy dotyczące człowieka poprzez fenomenologiczną metodę akcentującą przeżycia podmiotu. Można przypuszczać, że ów „pociąg” do jednoczesnego, przedmiotowego i podmiotowego sposobu uprawiania filozofii narodził się w nim nie tylko dzięki studiowaniu tomizmu i fenomenologii, ale także za sprawą mistycznej doktryny św. Jana od Krzyża, w której oba te podejścia są na swój sposób obecne. Dzięki temu jej wpływ rozciągałby się na całość filozofii, jaką uprawiał, w tym na jego koncepcję miłości.

Jednak dla niniejszych rozważań bardziej istotne jest raczej to, że owa inspiracja mistyczną doktryną zdaje się być dość wyraźnie widoczna w jego koncepcji zjednoczenia osób w miłości oblubieńczej, którą zawarł na kartach swojego studium etycznego Miłość i odpowiedzialność. $\mathrm{W}$ ramach tego ujęcia dopełnia on metafizyczne założenie o nieprzekazywalności osoby w porządku natury postulatem zjednoczenia osób w porządku miłości, które ma się dokonywać za sprawą mistycznego prawa „ekstazy”. Dlatego stwierdza się tu, że idea zjednoczenia osób wydaje się

51 Warto dodać, że Wojtyła dopełniał rozważania dotyczące zjednoczenia osób w miłości oblubieńczej nie tylko w ramach mistyki, ale również poezji. W jednym z fragmentów swojego dramatu zatytułowanego Przed sklepem jubilera porusza ten właśnie temat: „Miłość - miłość pulsuje w skroniach / w człowieku staje się myślą / i wolą: / wolą bycia Teresy Andrzejem, / wolą bycia Andrzeja Teresą. // Dziwne, a jednak konieczne / - i znów odchodzić od siebie, / bo człowiek nie przetrwa w człowieku / bez końca / i nie wystarczy człowiek. // Jakże uczynić, Tereso, / by pozostać na zawsze w Andrzeju? / Jakże uczynić, Andrzeju, / by pozostać na zawsze w Teresie? / Skoro człowiek nie przetrwa w człowieku/ i nie wystarczy człowiek" (K. Wojtyła, Poezje i dramaty, Kraków 1980, s. 195-196). 
być niejako punktem stycznym dla mistyki św. Jana od Krzyża oraz filozoficznej koncepcji miłości Karola Wojtyły ${ }^{52}$.

Trzeba jednak podkreślić, że powyższe spostrzeżenia nie wyczerpują omawianej tu problematyki. Stanowią one raczej próbę wstępnego jej zarysowania. Podejmowane tu kwestie zasługują bowiem na przeprowadzenie bardziej dogłębnych badań.

\section{Bibliografia}

Biesaga T., Mistyka i metafizyka w antropologii Karola Wojtyły, w: Wokót antropologii Karola Wojtyly, red. A. Maryniarczyk, P. Sulenta, T. Duma, Lublin 2016, s. 59-72. Buttiglione R., Myśl Karola Wojtyły, Lublin 2010.

Filek O., Wprowadzenie, w: św. Jan od Krzyża, Dzieła, Kraków 1995, s. 7-54.

Galarowicz J., Człowiek jest osobą. Podstawy antropologii filozoficznej Karola Wojtyty, Kraków 1994.

Maritain J., Pisma filozoficzne, Kraków 1988.

Serafin M. od Trójcy Przenajświętszej OCD, Geniusz św. Jana od Krzyża, Poznań 2009.

Św. Jan od Krzyża, Droga na górę Karmel, Kraków 2001.

Św. Jan od Krzyża, Noc ciemna, Kraków 2001.

Św. Jan od Krzyża, Pieśń duchowa, Kraków 2002.

Św. Jan od Krzyża, Żywy płomień miłości, Kraków 2003.

Wojtyła K., Aby Chrystus się nami posługiwał, Kraków 1979.

Wojtyła K., Miłość i odpowiedzialność, Lublin 2001.

Wojtyła K., Poezje i dramaty, Kraków 1979.

Wojtyła K., Świętego Jana od Krzyża nauka o wierze, Lublin 2000.

Wojtyła K., Zagadnienie podmiotu moralności, Lublin 2001.

Zdybicka Z., Jan Pawet II - filozof i mistyk, Lublin 2009.

52 Autor niniejszego artykułu pragnie złożyć podziękowania dr. Janowi Galarowiczowi za udzielenie cennych uwag dotyczących podejmowanych tu kwestii. 


\section{Abstrakt \\ Mistyka św. Jana od Krzyża w filozoficznej koncepcji miłości Karola Wojtyły?}

Artykuł porusza temat wpływu, jaki mogła mieć mistyczna doktryna św. Jana od Krzyża na filozoficzną koncepcję miłości Karola Wojtyły. Stawia się tu tezę, że oddziaływanie to mogło być dwojakie: pośrednie i bezpośrednie.

Wpływ pośredni polegałby na przyczynieniu się do przyjęcia przez Wojtyłę postawy filozoficznej, zawierającej dwa sposoby filozofowania: tomistyczny i fenomenologiczny. Postawa ta następnie warunkowałaby podejście Wojtyły do tematu miłości. Natomiast wpływu bezpośredniego można się doszukiwać w tych fragmentach Miłości i odpowiedzialności, gdzie rozważana jest miłość oblubieńcza, która - podobnie jak w mistyce św. Jana od Krzyża - skupia się na idei zjednoczenia osób.

\section{Słowa kluczowe}

św. Jan od Krzyża, Karol Wojtyła, mistyka, miłość

\section{Abstract \\ St. John of the Cross Mysticism in Karol Wojtyła's Philosophical Conception of Love?}

This article discusses the possible impact of the mystical doctrine of St. John of the Cross on Karol Wojtyła's conception of love. I formulate here the thesis that this influence could be two-fold: indirect and direct.

The indirect impact means the adoption of a philosophical attitude by Wojtyła containing two ways of philosophizing: Thomistic and phenomenological. In consequence, this attitude determines Wojtyła's approach to the subject of love. While the direct impact can be traced in these passages of Love and Responsibility where spousal love is considered. This love is focused on the idea of unification of persons like in the mysticism of St. John of the Cross.

\section{Keywords}

St. John of the Cross, Karol Wojtyła, mysticism, love 